IZA DP No. 5285

Quantity over Quality?

A European Comparison of the Changing Nature of Transitions between Non-Employment and Employment

Werner Eichhorst

Regina Konle-Seidl

Alison Koslowski

Paul Marx

October 2010 


\title{
Quantity over Quality? A European Comparison of the Changing Nature of Transitions between Non-Employment and Employment
}

\author{
Werner Eichhorst \\ $I Z A$
}

Regina Konle-Seidl

$I A B$

Alison Koslowski

University of Edinburgh

Paul Marx

$I Z A$

Discussion Paper No. 5285

October 2010

IZA

P.O. Box 7240

53072 Bonn

Germany

Phone: +49-228-3894-0

Fax: +49-228-3894-180

E-mail: iza@iza.org

Any opinions expressed here are those of the author(s) and not those of IZA. Research published in this series may include views on policy, but the institute itself takes no institutional policy positions.

The Institute for the Study of Labor (IZA) in Bonn is a local and virtual international research center and a place of communication between science, politics and business. IZA is an independent nonprofit organization supported by Deutsche Post Foundation. The center is associated with the University of Bonn and offers a stimulating research environment through its international network, workshops and conferences, data service, project support, research visits and doctoral program. IZA engages in (i) original and internationally competitive research in all fields of labor economics, (ii) development of policy concepts, and (iii) dissemination of research results and concepts to the interested public.

IZA Discussion Papers often represent preliminary work and are circulated to encourage discussion. Citation of such a paper should account for its provisional character. A revised version may be available directly from the author. 


\section{ABSTRACT \\ Quantity over Quality? A European Comparison of the Changing Nature of Transitions between Non-Employment and Employment}

This paper explores the empirical evidence for the claim that non-employed men and women in post-industrial labour markets are more likely to make the transition into employment than has previously been the case. It concludes that whilst the unemployed and the inactive remain distinct groups with regards to transitions into employment, post-industrial labour markets have indeed become more inclusive. Only a few countries saw decreased odds of transition over time for the unemployed, controlling for macro-economic conditions. The picture for the inactive is more mixed cross-nationally. Regarding the question whether an increasingly inclusive labour market is associated with a reduction in job quality, as measured by contract type, the study finds that there is a trend towards more precarious employment for the recently non-employed in some countries such as the Czech Republic, France, Italy and Belgium. In Denmark, Spain, the UK and Hungary, however, there was the opposite trend towards more permanent employment.

JEL Classification: J41, J62

Keywords: non-standard employment, fixed-term contracts, transitions

Corresponding author:

Werner Eichhorst

IZA

P.O. Box 7240

53072 Bonn

Germany

E-mail: eichhorst@iza.org 


\section{Introduction}

Reforms in unemployment protection might lead us to assume that inactive and unemployed men and women in post-industrial labour markets are more likely to make the transition into employment than has previously been the case. This paper explores the empirical evidence for such a claim. This sets the stage for a second, related question: Is an increasingly inclusive labour market associated with a reduction in job quality, as measured by contract type, for those most recently having made the transition from non-employment to employment? All countries covered in the volume are included in the cross-national analysis as far as European Labour Force Survey data availability allows, which means that eight countries are fully included: Belgium, Czech Republic, Denmark, France, Hungary, Italy, Spain and the UK.

\section{Linking unemployment protection, activation and labour market developments}

While more inclusive labour markets based on activating labour market and social policies imply that more people enter the labour market, an expansion in the number of jobs may be associated with new forms of duality with respect to the quality of jobs. This duality may be comprised of: a wider variety of contract types, more pronounced wage dispersion and substantial barriers to mobility from entry to more stable and better-paid jobs. Looking at the broad relationship between changes to unemployment protection and developments in labour markets, such a trade off between quantity and quality of jobs can be the result of three major trends which have occurred in parallel in virtually all European countries: (1) activation; (2) tertiarisation and (3) increased la- 
bour market flexibility. The degree of post-industrialism of national labour markets - in particular the spread of service sector employment with a larger share of atypical types of work - is likely to be linked with the scope of change within unemployment protection systems.

Do changes in unemployment protection generate changes in the labour markets such as lower inactivity via the spread of atypical work and the increase of a low wage sector - or do changes in the labour market such as an increase in atypical work and the corresponding low coverage by unemployment insurance, require changes in the protection system? It is beyond the scope of the paper to determine the direction of such correlation or even perhaps, a causal relationship. Rather, it is plausible to assume that there is a delicate, mutually reinforcing development between the growth of the service economy, increasing labour market flexibility and activation policies. However, we can determine whether labour markets have become more inclusive, if more heterogeneous. We can observe changes to the risk of the non-employed finding permanent employment over time and across countries.

\subsection{Activation and its impact on the labour market}

Labour market policy across the OECD has moved towards a stronger employment orientation in the past two decades. Activation policies have made passive benefit receipt less legitimate and attractive. The road to economic self-sufficiency in last resort benefit systems is taking up a job in order to end benefit dependency. The work requirement stemming from activation policies means that it has become less attractive for the unemployed, including those not actively looking 
for a job, to claim benefits. As a consequence, the unemployed may either leave the labour force or become genuine job seekers with lower reservation wages.

In general, either demanding or enabling interventions (or combinations of both) further exit into regular or subsidized jobs: Work support measures like in-work benefits have been implemented in many countries and more integrated services are offered to job searchers. Across countries more "work first" policies have been developed resulting in less emphasis on extended training programmes or purely “passive” benefit receipt (Konle-Seidl and Eichhorst, 2008).

However, work requirements and mandatory programme participation do not only affect the fraction of unemployed in activation programmes but also other groups of the labour force, namely the unemployed in general as well as the employed - and even the economically inactive members of the working-age population. The employed may be affected indirectly as out-of-work options become less attractive. Wage bargaining models predict under very general assumptions that this will lead to lower wage demands, i.e. the mark-up of wages over benefits is reduced. Lower wages will, in turn, be conducive to employment. A necessary condition for this supply side effect to be present is that there is both a downward pressure on wage setting and an upward move in employment.

From a theoretical perspective, activation may increase wage flexibility by inducing lower reservation wages. Like the lowering of replacement rates, compulsory activation measures such as imposing additional search requirements or mandatory programme participation aim at changing the returns from work relative to benefit receipt. In the end this implies a behavioural change leading to potentially lower reservation wages and higher search efforts contributing to a strengthening of work incentives (Andersen and Svarer, 2008). 
Since in-work benefits make employment, even in low paid jobs, more attractive relative to unemployment, this also facilitates wage moderation. In-work benefits are designed to create work incentives. However, in times when the labour market is weak they can facilitate continued work attachment for those already in employment, thus redistribution and avoidance of poverty becoming more important than employment creation. During a subsequent recovery it can be expected that in-work benefits support outflows from unemployment (see, e.g. Immervoll and Pearson, 2009).

\subsection{Labour market flexibility as a by-product of tertiarisation}

At the same time, but not necessarily directly related to reforms in unemployment protection and active labour market programmes, the very nature of employment has changed over the last decade. Compared to the situation in 1997 when $27 \%$ of all workers in the EU-15 were still employed in manufacturing and 69\% in services, by 2009 the service sector made up $74 \%$ of overall employment (22\% in manufacturing). Particularly strong growth could be observed in businessrelated, social and personal services in most countries.

The share of standard open-ended full-time contracts which were typical for manufacturing jobs has declined in virtually all European countries. This was not associated with a shrinking number of jobs overall, but rather with an enormous growth of both public and private service sector employment, new types of occupations and a larger share of flexible or "atypical" contracts, which are particularly pervasive in the private service sector (OECD, 2001). Notwithstanding differences across countries and service subsectors, however, it is fair to say that major dynamic parts of the service sector operate outside traditional open-ended full-time contracts covered by collec- 
tive agreements, full social insurance coverage and long tenure. In services, we find larger shares of part-time work, fixed-term contracts, self-employment as well as low pay.

Given the fact that employment rates rose across European countries, this has meant an even larger increase in the absolute number of jobs created by the service sector, which more than compensate for the jobs lost in manufacturing. Hence, there is a strong long-term trend from manufacturing to service sector employment, which makes up for the vast majority of jobs in current European labour markets.

Tertiarisation is driven by global economic integration, technological change and, equally important, demographic change, in particular ageing and strongly increasing female labour force participation, which in turn also generates demand for services delivered to households. Technological change and global economic integration tend to mutually reinforce each other and accelerate structural change in the economy. This, in turn, makes continued employment in exposed sectors more demanding. Low skilled workers, whom the manufacturing sector can no longer absorb, face particular difficulties. However, service employment poses different skills demands to manufacturing. Mobility across sectors and occupations generates a major challenge to labour market policies as costly labour supply reduction policies such as early retirement are phased out. Workers with insufficient and obsolete qualifications risk being referred to low pay and insecure jobs when activated, if the provision of retraining is inappropriate or ineffective. Hence, most entry jobs for labour market entrants and activated non-employed are expected to be provided by the service sector, resulting in a greater heterogeneity of working conditions. At least partial deregulation of labour markets has facilitated this.

\subsection{Partial labour market deregulation and increasing dualisation}


Labour market deregulation has played a major role in allowing for the creation of service sector jobs and more heterogeneity in the labour market. Over the last two or three decades there has been a general tendency to deregulate labour markets, in particular with respect to flexible or “atypical” forms of employment. This has been done with a double motivation: the first was to create additional jobs by lowering the barriers that employers face when hiring additional staff, in particular small service sector firms, the second was to establish a segment of entry jobs which could act as a stepping stone towards "regular” employment.

The potential for employment growth in an increasingly post-industrial labour market could only be realised by the service sector, with its stronger reliance on external labour market flexibility. Hence, the liberalization of fixed-term contracts, agency work, self-employment and start-ups as well as the active promotion of job creation in these areas by means of active labour market policies has been on the agenda of all countries compared. Comparative institutional indicators developed by the OECD show a general tendency to reduce the level of regulation regarding fixedterm jobs, temporary agency work and barriers to self-employment (Venn, 2009). In empirical terms, this has facilitated job creation such as agency work, which deviates from "standard employment”. This is shown in table 1 , which also presents evidence that low pay has become more frequent in a number of countries - if not all - over the last decade. Figure 1, furthermore, shows the evolution of the share of workers with fixed-term contracts (including apprentices) over time. Contrary to some beliefs, however, there has only been a slight increase in the country average from $12.2 \%$ in 1998 to a peak of $13.5 \%$ in 2007 . Fixed-term employment has decreased to $12.7 \%$ since then. Average figures, however, hide a considerable degree of variation at the national level. More heavy reliance on fixed-term jobs can mostly be observed in labour markets with 
strict dismissal protection such as Spain and Italy, but also in the Netherlands and Sweden. Fixed-term contracts have become less important in Denmark or the UK.

Table 1 and Figure 1 to be added here

While liberalising non-standard jobs can facilitate job creation, this trend also means that a larger share of workers are not (fully) covered by social insurance or do not exhibit a sufficient employment record in order to be entitled to unemployment insurance benefits. Substantial shares of unemployed people do not in fact qualify for insurance-related benefits. In part, this is intended. They may be excluded by law (e.g. the self-employed in most countries, including the so-called “bogus” self-employed) or de facto because they are less likely to meet contribution requirements or satisfy other relevant eligibility criteria (e.g. temporary or part-time workers). This has triggered at least three types of reforms: first, there is evidence that policy makers have tried to maintain or even reinforce the link between contributions and benefits and therefore exclude those with short or interrupted work histories; second, in some cases access to social insurance benefits has been eased or dynamically growing categories of employment (e.g. freelancers) have been integrated into the system; third, at the same time in many countries minimum standards, in particular means-tested income protection, have been reinforced institutionally and grown in importance relative to unemployment insurance (see, e.g. Hemerijck and Eichhorst, 2010).

\subsection{What do we know from empirical research? Findings in the literature}


What do we know from empirical research? First, there are quite robust findings across countries from micro-econometric studies with regard to the short-term effectiveness of demanding elements such as mandatory participation in activation programmes, job-search monitoring or reducing maximum benefit duration ${ }^{1}$. Andersen and Svarer (2008) show, for example, that the threat of mandatory participation in activation programmes even has a positive impact on the search effort of those unemployed persons not yet assigned to a workfare programme.

Threat and screening effects seem to have an important impact on job-finding and benefit caseloads. Evidence on net re-employment effects of voluntary or mandatory programme participation is less robust. However, work first measures are often ineffective in lifting the individuals and their families out of poverty on a sustainable basis (Moffit, 2008; Bolvig, 2003).

Given displacement, substitution, deadweight, wage and fiscal effects, the macro-economic effectiveness and efficiency of activation programmes as well as the sustainability of effects is less clear. In particular, some studies point at the fact that activating interventions based on the threat potential and demanding principle may help move benefit recipients to low-skill, low-pay and unstable jobs so that they run the risk of continued partial reliance or repeated return to benefits.

Germany is an illustrative case for this type of revolving door effect. The first wave of the German PASS - introduced to monitor the effects of the Hartz IV reform (2005) - shows that within less than a year, $14 \%$ of UB II recipients have left benefit rolls. About 50\% of those leavers are becoming self-sufficient by taking up a full (78\%) or a part-time job of at least 16 hours a week and $5 \%$ of leavers take up a subsidized job. About one in four are taking up jobs below their formal skill-level. Gross hourly wages are below $7.50 €$ for nearly half of the leavers. $36 \%$ find tem-

\footnotetext{
${ }^{1}$ For an overview of the available evidence see Konle-Seidl and Eichhorst, 2008. For a recent meta-analysis of evaluation studies see Card, Kluve and Weber, 2009.
} 
porary jobs, $12 \%$ find temp agency work and between $32 \%$ and $46 \%$ of those leaving benefit rolls in 2006 and 2007 have taken up a "standard work arrangement". However, only further waves of PASS will show whether flexible jobs are a spring board to more stable and better paid jobs for those ending benefit receipt, or whether they rather constitute a revolving door back to benefit receipt (Achatz and Trappmann, 2009).

A similar picture is given by leaver surveys of New Deal participants in the UK. Around $40 \%$ of NDYP (New Deal for Young People) participants who find work claim JSA again within a year. This pattern of recycling between benefits and programmes has been found also in the other New Deals. However, there is no information on the type of jobs found by New Deal leavers. In a survey the majority (72\%) of “repeaters" who made at least three claims for Jobseeker's Allowance indicated that they had not been able to find "suitable" work. The main problem was the type of work available rather than not being able to find work at all (Carpenter, 2006).

Second, surprisingly little is known about the effects of activation policies on wages. There is a general lack of empirical research on the wage moderation and wage setting effects of both the demanding side of activation like mandatory programme participation or benefit cuts as well as the promoting side like in-work benefits. Graafland and Huizinga (1998), for example, found that the wage-moderating effect of lower replacement rates is stronger during periods of high unemployment. Kettner and Rebien (2007) were able to show with data from business surveys taken in 2005 and 2006 for Germany, that from the firm’s perspective, the unemployed are willing to take more concessions in earnings and working terms after the Hartz reforms than they did in the past. For Denmark, Bolvig (2008) shows that tightening unemployment insurance benefits led to a stronger inflow from unemployment into low pay jobs, limited upward mobility and more unstable careers for less skilled people, who would otherwise have remained on benefits. 
Evaluation studies focusing on the transition from unemployment to work rarely focus on the type of job taken up. One exception is a Dutch study by Zijl, van den Berg and Heyma (2004) showing that temporary jobs effectively provide a stepping stone for the unemployed towards regular jobs compared to a situation without temporary jobs - however the study does not study potential side effects of increases in temporary work. More is known about mobility from nonstandard to standard and from low pay to medium pay. First, there is evidence of strong differences between countries in mobility from fixed-term to permanent contracts. In some countries such as France the risk of longer spells under (renewed) fixed term contracts is much higher than, for example, in Germany (Gebel and Giesecke, 2009; Gash, 2008; Blanchard and Landier, 2002). This can be seen as a direct consequence of regulatory differentials between permanent and fixed-term contracts. Furthermore, studies on Germany could not find clear evidence regarding a significant stepping stone effect of agency work for labour market entrants in Germany (Kvasnicka, 2009; Lehmer and Ziegler, 2010). Regarding pay mobility, a recent German study found strong differences by qualification, age, type of job, firm, and occupation (Mosthaf, Schnabel and Stephani, 2010). It seems fair to argue that most studies suggest that non-standard employment has become a permanent feature of post-industrial labour markets as atypical work provides additional flexibility and often lower labour costs, which are particularly important with respect to important segments of the service sector. Countries vary greatly with respect to their reliance on particular types of employment and the likelihood of non-standard workers making a transition to permanent jobs (Eichhorst and Marx, 2010).

These three trends lead us to assume that the formerly unemployed or inactive persons tend (i) to enter the labour market more frequently than at earlier points in time and (ii) are mostly doing so 
using non-standard jobs as entry points with the prospect of both stabilization of the employment record (sustainability of employment) and upward mobility; (iii) the service sector comes in as an alternative or the only job-creating sector relevant for labour market entrants, in particular after longer spells of inactivity or unemployment. The three trends of activation, tertiarisation and labour market flexibility lead us to assume the following hypotheses, which will be explored empirically in the remainder of this paper:

H1: Formerly unemployed or inactive persons tend to enter the labour market more frequently than at earlier points in time.

H2: This is mostly achieved using jobs associated with atypical employment contracts..

\section{Have labour markets become more inclusive? An empirical analysis based on the European Labour Force Survey}

There are various ways to approach the question of whether labour markets have become more or less inclusive between the late 1990s and the late 2000s. We might expect to observe a more diverse composition of the labour force given the increased labour market participation of women (OECD, 2008). We might also expect to see decreased numbers of non-employed, as discussed above. In this paper, we are particularly interested to see whether unemployed and inactive individuals are increasingly likely to make the transition into employment. We are also interested, if we do find a more inclusive labour market, in whether this also extends to quality of contract. ${ }^{2}$

\footnotetext{
${ }^{2}$ It would also be worthwhile to consider wages levels, the duration of unemployment and other spells of nonemployment, but this is beyond the scope of the current analysis. There is a lack of comparative data concerning wage and income levels. The prevalence of non-standard jobs would be a further route of enquiry.
} 
One way to consider whether labour markets have become more inclusive is to look at transition rates. There is a relative paucity of comparative European Union data from which to calculate transition rates from non-employment to employment. The main sources, often incomplete, which include information on pay, employment and type of contract type, are the European Community Household Panel (from 1994 - 2001 for the EU-15) and EU-SILC (2002-ongoing for the since enlarged European Union) (European Commission, 2009). Other than this, transition rate data are drawn from national sources that are not normally directly comparable.

The European Labour Force Survey (ELFS), a harmonised collection of Labour Force Survey data as produced by the EU-25 countries, can also be used to compute transition rates. It has far greater coverage than any other available data, both in terms of sample size and the number of countries covered over a substantial period of time. For many countries, data are available from 1983 to the current day. This potential for the analysis of trends over time and between countries has been recognised in a number of publications (e.g. Mazzuco and Suhrcke, 2010).

Clearly, the harmonisation of such a large data set across time and countries is a challenge and at times comparability between data tables is inevitably compromised (Charlier and Franco, 2001). For our analysis, it should be noted that the construction of the "annual" data sets is not the same between the two time periods. To take the example of Belgium, the 1997 data is collected in quarter 2 (weeks 14 - 26 of the year) and there are 80,373 observations. However, in 2007 the Belgian data are collected from observations across the yearly period and there are 111,978 observations. One thought, so as to compare like with like would be to look only at quarter 2 data for 2007 (as recorded in the annual data set be2007_y). This yields 26,578 observations, which is a much reduced sample size. There are quarterly available data sets available, in addition to the annual data. However, Eurostat advise that the annual datasets "be considered as the best sample 
available to cover all variables and allow all cross-tabulations" including a yearly weighting factor (European Commission, 2010b). For our analysis, we use the yearly harmonised ELFS data and not the quarterly data sets as they do not appear to contain the full range of harmonised variables.

In table 2 it can be seen that for most countries, the percentage of the non-employed making a transition to employment does indeed appear to have increased between 1997 and 2007 across Europe, particularly for the unemployed.

- Insert table 2 about here -

In order to control for the nature of the composition of the groups of unemployed and inactive persons making a transition to employment, we turn to a logistic regression model, again using the ELFS. Our first model considers, for those of working age (between 16 - 65 years) whether a transition is more likely in the late 2000s than in the late 1990s, controlling for other factors (sex, age, education level, country and real GDP growth rate). The equation to follow describes a logistic regression model. The dependent variable in a logistic regression is the log of the odds ratio.

$\operatorname{Ln}[p /(1-p)]=B_{0}+B_{i} X(\text { year }, \text { country, sex, age, education, GDP growth })_{i}+e$

In this first model $p$ is the probability of making a transition from non-activity or unemployment to employment. The vector $X_{i}$ consists of the following characteristics: whether the transition was made recently (2007) as compared to 1997, country, sex, age, education level and the real GDP growth rate. 
Whilst the EU-LFS are a collection of cross-sectional (rather than longitudinal) data sets, this analysis is able to exploit a lagged variable which acquires retrospective information on an individual's situation with regard to activity one year before the survey. This variable captures information as to whether the person was employed ${ }^{3}$, unemployed or otherwise inactive ${ }^{4}$ in the previous year. If individuals indicate that they were either unemployed or inactive in the previous year, and employed in the current year, they are deemed to have made a transition. The variable in question (wstat1y) is not available for every country for every year and suffers from varying degrees of missing data. This is particularly the case for Sweden and the Netherlands, which are excluded from analysis on these grounds. German data for late-1990s were not available either.

The independent variable of central interest is the year. Is there a noticeable change between 1997 and 2007? Country dummies are included to capture the difference between countries. The UK serves as the reference category. The usual suspects are also included in the model to control for changes in composition. These are: whether the individual is male or not; age measured in years and age squared; education level coded according to the International Standard Classification of Education (ISCED 97), low level of education is the reference category. We also control for macro-economic conditions using the real GDP growth rate.

- Insert table 3 about here -

In order to address the question of whether labour markets have become more inclusive between the years 1997 and 2007, logistic regressions are estimated and odds ratios are reported, to give

\footnotetext{
${ }^{3}$ Employed is defined in the ELFS as "carries out a job or profession, including unpaid work for a family business or holding, including an apprenticeship or paid traineeship, etc".

${ }^{4}$ Inactive is defined in the ELFS as "pupil, student, further training, unpaid work experience; in retirement or early retirement or has given up business; permanently disabled; in compulsory military service; fulfilling domestic tasks; other inactive person.” Not all categories are collected for all countries.
} 
insight to the odds of someone who was either unemployed or inactive in the previous year, making the transition into any form of employment. The odds ratio is a way of comparing whether the probability of a certain event is the same for two groups. An odds ratio of 1 implies that the event is equally likely in both groups. An odds ratio greater than one implies that the event is more likely than in the reference category in the case of dichotomous explanatory variables, such as country. An odds ratio of less than one implies that the event is less likely than in the reference category.

To begin with, all countries are pooled together and the unemployed and the inactive are grouped together (see table 4). This model suggests that there is a pan-European trend over time, towards labour markets becoming more inclusive with respect to increased odds (the odds ratio is 1.17) of a non-employed (unemployed person or inactive) person making the transition to employment. Separate models are run for those potentially making the transition from unemployment and for those potentially making the transition from inactivity. The odds ratio for the unemployed is greater (1.40) than for the inactive (1.11) (figure 2).

- Insert table 4 about here -

- Insert figure 2 about here -

It is apparent that there is variation between countries, with regard to the trends towards increasing transition (in reference to the UK). Only in Denmark was a transition more likely than in the UK (table 4). All other countries in the analysis were less likely to see a transition. Separate 
models were also run for each country and for each group (the unemployed and the inactive). The odds ratios are presented for the key variable of interest (2007 rather than 1997) in figures 3 and 4. Figure 3 shows that the unemployed were more likely to make the transition to employment in 2007 in most countries in the analysis (Belgium, Denmark, Spain, France and the UK), with only the Czech Republic and Italy being different in this respect. The data for Hungary were inconclusive. Figure 4 shows that the inactive were more likely to make the transition to employment in Belgium, Spain and France, but less likely in the Czech Republic, Hungary and Italy. Results for the inactive in the UK and Denmark are inconclusive as they are not statistically significant.

- Insert figure 3 about here -

- Insert figure 4 about here -

\section{$4 \quad$ The changing nature of labour market transitions}

We have been able to show thus far, that labour markets have become more inclusive for the unemployed in many countries, if not all, also for the inactive. In this section, we employ an innovative approach to explore whether the increase in labour market inclusion with respect to those making the transition from non-employment has been accompanied (at the aggregate level) by an increase in more precarious employment. More insecure employment here is measured by contract type, specifically as non-permanent contracts or self-employment. ${ }^{5}$

Unfortunately, it is not possible to look at pay due to limitations of data availability. 
In reference to equation (1), in this second group of models, $p$ is the probability, having made a transition, that the transition has been into a permanent as compared to a temporary contract. The vector $X_{i}$ consists of the following characteristics: whether the transition was made recently (2007) as compared to in (1997), country, sex, age and age-squared, education level, the real GDP growth rate, and sector of employment (agriculture, industry or service).

For each of the countries for which data are available, we exploit again the lagged employment status variable in the European Labour force survey. Logistic regressions, reporting odds ratios, are estimated to give insight to the odds of someone who has made the transition from nonemployment to employment in 2007, as opposed to in 1997, making the transition into permanent employment rather than into self-employment or a fixed term contract. The EU-LFS data are used as before, with the addition of a variable to control for sector of employment: agriculture, industry and service. The service sector is taken as the reference category.

As expected, the pooled model containing all countries finds that a pan-European trend towards more insecure employment. The odds have decreased slightly (the odds ration is 0.93) between 1997 and 2007 of making a transition from non-employment into a permanent contract (table 5).

However, looking country by country reveals a split picture (figure 5). With respect to those making a transition from non-employment, those in Denmark, Spain, UK and Hungary (although this coefficient is statistically significant only at the $10 \%$ level) were more likely to find permanent employment in 2007 as compared to 1997. Those in the Czech Republic, France, Italy and possibly Belgium (although this coefficient is statistically insignificant) were less likely to find permanent employment in 2007 as compared to 1997. 
- Insert table 5 about here -

- Insert figure 5 about here -

\section{Summary}

This paper has explored the empirical evidence for the claim that non-employed men and women in post-industrial labour markets are more likely to make the transition into employment than has previously been the case. Our results show that, as a general trend, post-industrial labour markets have indeed become more inclusive as the transition rate of the unemployed and the inactive into employment has increased in 2007 compared to 1997. However, the unemployed and inactive remain distinct groups with regards to transitions into employment. Just two countries (the Czech Republic and Italy) out of the eight considered saw decreased odds of transition over time for the unemployed, controlling for macro-economic conditions. The picture for the inactive is more mixed cross-nationally. Labour markets have become more inclusive for the inactive in Belgium, Spain, France, but not in the Czech Republic, Hungary, Italy and possibly Denmark and the UK.

A second, related question asks whether an increasingly inclusive labour market is associated with a reduction in job quality, as measured by contract type. There is a trend towards more insecure employment for the recently non-employed in the Czech Republic, France, Italy and possibly Belgium. However, in the other countries considered, Denmark, the UK and Hungary, there was the opposite trend towards more permanent employment. One can also observe a slight de- 
cline in the otherwise very high incidence of fixed-term employment in Spain. This might reflect differences in the stability and institutional set-up of permanent employment. 


\section{References}

Achatz, Juliane and Mark Trappmann, 2009: Befragung von Arbeitslosengeld-II-Beziehern: Wege aus der Grundsicherung, IAB Kurzbericht 28/2009. Nürnberg: IAB.

Andersen, Torben M. and Michael Svarer, 2008: The role of workfare in striking a balance between incentives and insurance in the labour market, CESifo Working Paper 2267.

Arranz, Jose M., Maria A. Davia and Carlos García-Serrano, 2005: Labour Market Transitions and wage dynamics in Europe. ISER Working Paper 2005-17. Colchester: University of Essex.

Blanchard, Olivier and Augustin Landier, 2002: The Perverse Effects of Partial Labour Market Reform: fixed--Term Contracts in France, The Economic Journal. Vol. 112, No. 480, F214F244.

Bolvig, Iben, Peter Jensen and Michael Rosholm, 2003: The Employment Effects of Active Social Policy. IZA Discussion Paper 736. Bonn: IZA.

Bolvig, Iben, 2008: Low-wage work after unemployment - the effect of changes in the UI system. University of Aarhus Economics Department Working Paper 08-11.

Card, David, Jochen Kluve and Andrea Weber, 2009: Active Labour Market Policy Evaluation: A Meta-Analysis. IZA Discussion Paper 4002. Bonn: IZA.

Carpenter, Hannah (2006): Repeat jobseeker’s allowance spells. DWP Research report N³94,

Charlier, Hubert and Ana Franco, 2001: The EU Labour Force Survey on the Way to Convergence and Quality, Proceedings of Statistics Canada Symposium 2001 Achieving Data Quality in A Statistical Agency: A Methodological Perspective, Ottawa, Canada: Statistics Canada.

Eichhorst, Werner and Paul Marx, 2010: Whatever Works: Dualisation and the Service Economy in Bismarckian Welfare States. IZA Discussion Paper 5035. Bonn: IZA.

European Commission, 2010a: Compendium, July 2010 <http://ec.europa.eu/social/BlobServlet?docId=4093\&langId=en> Accessed, 31 ${ }^{\text {st }}$ May, 2010.

European Commission, 2010b, The European Labour Force Survey, http://circa.europa.eu/irc/dsis/employment/info/data/eu_lfs/lfs_main/lfs/dissemination_structu re.htm Accessed 28th September, 2010.

Gash, Vanessa, 2008: Bridge or Trap? Temporary Workers' Transitions to Unemployment and to the Standard Employment Contract. European Sociological Review. Vol. 24, No. 5, 651-688.

Gebel, Michael and Johannes Giesecke, 2009: Labour market flexibility and inequality: the changing risk patterns of temporary employment in West Germany. Zeitschrift für Arbeitsmarktforschung. Vol. 42, No. 3, 234-251.

Graafland, Johan J. and Frederik H. Huizinga, 1998: Taxes and benefits in a non-linear wage equation, MPRA Paper 21076, 
Hemerijck, Anton and Werner Eichhorst, 2010: Whatever Happened to the Bismarckian Welfare State? From Labor Shedding to Employment-Friendly Reforms. In: Palier, Bruno (ed.), A long good-bye to Bismarck. Amsterdam: Amsterdam University Press, 301-332.

Immervoll, Herwig and Mark Pearson, 2009: A good time for making work pay? Taking stock of in-work benefits and related measures across the OECD. OECD Social, Employment an Migration Working Paper 81. Paris: OECD.

Kettner, Anja and Martina Rebien, 2007: Hartz-IV-Reform: Impulse für den Arbeitsmarkt. IAB Kurzbericht 19/2007. Nürnberg: IAB.

Konle-Seidl, Regina and Werner Eichhorst, 2008: Does activation work? In: Eichhorst, Werner, Otto Kaufmann and Regina Konle-Seidl (eds.), Bringing the jobless into work? Experiences with activation schemes in Europe and the US. Berlin: Springer, 415-443.

Kvasnicka, Michael, 2009: Does Temporary Help Work Provide a Stepping Stone to Regular Employment? In: Autor, David H. (ed.), Studies of labor market intermediation. Chicago: University of Chicago Press, 335-272.

Lehmer, Florian and Kerstin Ziegler, 2010: Zumindest ein schmaler Steg. IAB Kurzbericht 13/2010. Nürnberg: IAB.

Mazzuco, Stefano and Marc Suhrcke, 2010: Health Inequalities in Europe: new insights from European Labour Force Surveys, Journal of Epidemiology and Community Health, Online First, published on July 30, 2010 as 10.1136/jech.2009.096271

Moffitt, Robert, 2008: Welfare reform: the US experience. With comments by Knut Røed. IFAU Working Paper 13/2008.

Mosthaf, Alexander, Claus Schnabel and Jens Stephani, 2010: Low-wage careers: are there deadend firms and dead-end jobs? IZA Discussion Paper 4696. Bonn: IZA.

OECD, 2001: OECD Employment Outlook, Chapter 3. Paris: OECD.

OECD, 2008: OECD Employment Outlook, Chapter 3. Paris: OECD.

Venn, Danielle, 2009: Legislation, Collective Bargaining and Enforcement: Updating the OECD Employment Protection Indicators. OECD Social, Employment and Migration Working Paper 89. Paris: OECD.

Zijl, Marloes, Gerard J. van den Berg and Arjan Heyma, 2004: Stepping Stones for the Unemployed: The Effect of Temporary Jobs on the Duration until Regular Work. IZA Discussion Paper 1241. Bonn: IZA. 
Table 1: Different forms of non-standard employment

\begin{tabular}{|l|c|c|c|c|}
\hline & \multicolumn{2}{|c|}{$\begin{array}{c}\text { Wage dispersion D5 } \\
\text { - D1 }\end{array}$} & \multicolumn{2}{c|}{$\begin{array}{c}\text { Share of temporary } \\
\text { agency workers }\end{array}$} \\
\hline & $\mathbf{1 9 9 8}$ & $\mathbf{2 0 0 8}$ & $\mathbf{1 9 9 7}$ & $\mathbf{2 0 0 8}$ \\
\hline Belgium & 1.41 & 1.38 & 1.3 & 2.1 \\
\hline Czech Republic & 1.66 & 1.73 & n.a. & 0.7 \\
\hline Denmark & 1.48 & 1.57 & 0.2 & 0.7 \\
\hline Germany & 1.75 & 1.93 & 0.4 & 2.0 \\
\hline Spain & n.a. & 1.66 & 0.5 & 0.7 \\
\hline France & 1.58 & 1.47 & 1.3 & 2.3 \\
\hline Italy & n.a. & 1.55 & 0.0 & 0.9 \\
\hline Hungary & 1.93 & 1.74 & 0.8 & 1.4 \\
\hline Netherlands & 1.66 & 1.65 & 2.1 & 2.9 \\
\hline Sweden & 1.37 & 1.37 & 0.3 & 1.3 \\
\hline Switzerland & 1.49 & 1.47 & 0.6 & 1.7 \\
\hline United Kingdom & 1.84 & 1.83 & 2.6 & 4.1 \\
\hline
\end{tabular}

Sources: OECD for wage dispersion (for Belgium 1999 instead of 1999, and 2005 instead of 2008 for the Netherlands, 2007 for Belgium and France, for low pay); figures only refer to fulltime workers; EURO CIETT for agency work (for Italy 1998, Hungary 2002 instead of 1997). 


\section{Figure 1: Share of fixed-term employment}

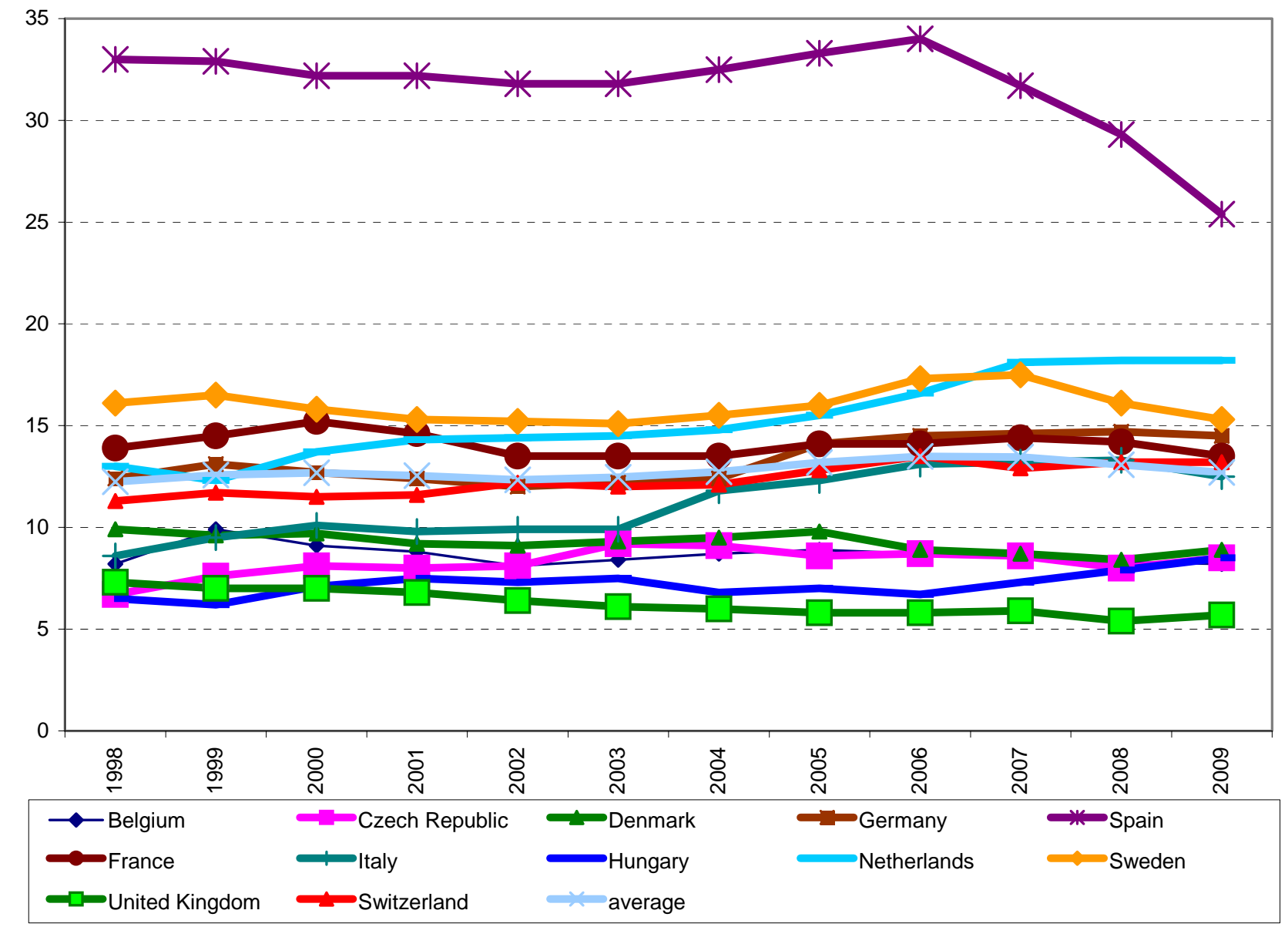

Source: Eurostat. 
Table 2: Transition rates from unemployment and inactivity to employment (\% of those unemployed \& inactive at t-1 making the transition to employment at t)

\begin{tabular}{|l|l|l|l|}
\hline Country & Year (t) & $\begin{array}{l}\text { \% unemployed at } \\
\text { t-1 making transi- } \\
\text { tion to employment }\end{array}$ & $\begin{array}{l}\text { \% inactive at t-1 } \\
\text { making transition } \\
\text { to employment }\end{array}$ \\
\hline Belgium & 1997 & 17 & 3 \\
\hline Belgium & 2007 & 20 & 8 \\
\hline Czech Rep. & $1998^{*}$ & 46 & 14 \\
\hline Czech Rep. & 2007 & 34 & 11 \\
\hline Denmark & 1997 & 36 & 29 \\
\hline Denmark & 2007 & 44 & 27 \\
\hline France & 1997 & 32 & 8 \\
\hline France & 2007 & 35 & 10 \\
\hline Germany** & 1997 & $(24)$ & $(14)$ \\
\hline Germany** & 2007 & $(31)$ & $(21)$ \\
\hline Hungary & 1997 & 30 & 6 \\
\hline Hungary & 2007 & 31 & 6 \\
\hline Italy & 1997 & 26 & 6 \\
\hline Italy & 2007 & 31 & 6 \\
\hline Spain & 1997 & 32 & 9 \\
\hline Spain & 2007 & 44 & 11 \\
\hline UK & 1997 & 40 & 16 \\
\hline UK & 2007 & 50 & 16 \\
\hline Not: & Key & & 6 \\
\hline
\end{tabular}

Note: * Key variable for this analysis missing for Czech Republic for 1997, so 1998 data are used. ** The German transition rates were not computed on the basis of ELFS data, but were calculated analogously with data from the German Socio-Economic Panel (GSOEP). Due to methodological differences (panel data instead of a retrospective question), the German results are not comparable to the rest of the sample. Source: ELFS data, weighted. Authors' own calculations. 
Table 3: Real GDP growth rate (volume) - percentage change on previous year

\begin{tabular}{|l|l|l|}
\hline Year & $\mathbf{1 9 9 7}$ & $\mathbf{2 0 0 7}$ \\
\hline Belgium & 3.7 & 2.9 \\
\hline Czech Republic & -0.8 (for 1998) & 6.1 \\
\hline Denmark & 3.2 & 1.7 \\
\hline France & 2.2 & 2.4 \\
\hline Italy & 1.9 & 1.5 \\
\hline Hungary & 4.3 & 1 \\
\hline Spain & 3.9 & 3.6 \\
\hline UK & 3.3 & 2.7 \\
\hline
\end{tabular}

Source: Eurostat Annual National Accounts. 
Figure 2: Logistic Regression Odds Ratios for the Transition to Employment from Non-Employment the previous survey year (t-1), in 2007 as compared with 1997.

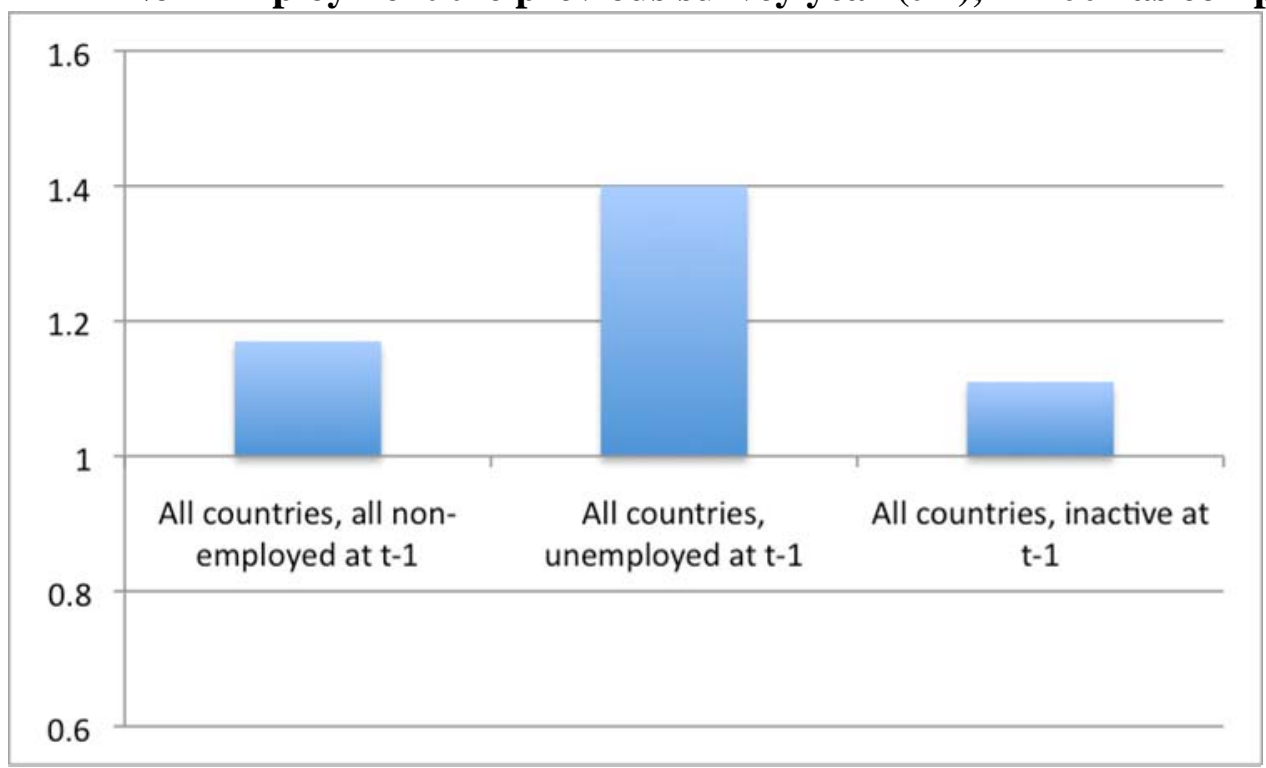

Note: An odds ratio of 1 implies that the event is equally likely in both 1997 and 2007.

An odds ratio greater than one implies that the event is more likely in 2007 than in 1997.

An odds ratio of less than one implies that the event is less likely in 2007 than in 1997 
Table 4: Logistic Regression: Transition from Non-employment (unemployment and inactivity) to employment

\begin{tabular}{|l|l|l|l|l|l|l|}
\hline \multicolumn{2}{|l|}{ Transition to employment } & $\begin{array}{l}\text { Odds Ra- } \\
\text { tio }\end{array}$ & $\begin{array}{l}\text { Robust } \\
\text { Std. Err. }\end{array}$ & $\mathbf{z}$ & $\mathbf{P}>\mathbf{z}$ & \multicolumn{9}{l|}{ Confidence Inter- } \\
val & & & 1.20 \\
\hline $2007(1)$ & 1.17 & 0.01 & 12.82 & 0.000 & 1.14 & 1.91 \\
\hline Male (2) & 1.87 & 0.02 & 50.12 & 0.000 & 1.82 & 1.24 \\
\hline age & 1.23 & 0.003 & 73.95 & 0.000 & 1.22 & 0.9968 \\
\hline age & 1.00 & 0.00004 & -83.12 & 0.000 & 0.9967 & 2.98 \\
\hline $\begin{array}{l}\text { High level } \\
\text { education } \\
\text { (3) }\end{array}$ & 2.88 & 0.05 & 57.82 & 0.000 & 2.77 & \\
\hline $\begin{array}{l}\text { Medium } \\
\text { level edu- } \\
\text { cation (3) }\end{array}$ & 1.59 & 0.02 & 35.66 & 0.000 & 1.55 & 1.63 \\
\hline Country (4) & & & & & & \\
\hline Belgium & 0.34 & 0.007 & -50.43 & 0.000 & 0.32 & 0.35 \\
\hline Czech Rep. & 0.72 & 0.01 & -16.51 & 0.000 & 0.70 & 0.75 \\
\hline Denmark & 1.81 & 0.06 & 19.18 & 0.000 & 1.71 & 1.92 \\
\hline Spain & 0.63 & 0.01 & -23.18 & 0.000 & 0.61 & 0.65 \\
\hline France & 0.59 & 0.01 & -24.75 & 0.000 & 0.57 & 0.62 \\
\hline Hungary & 0.41 & 0.009 & -40.70 & 0.000 & 0.40 & 0.43 \\
\hline Italy & 0.44 & 0.007 & -48.96 & 0.000 & 0.43 & 0.46 \\
\hline $\begin{array}{l}\text { GDP } \\
\text { growth }\end{array}$ & 0.96 & 0.004 & -10.32 & 0.000 & 0.95 & 0.97 \\
\hline Note: Refer| & & & & & \\
\hline
\end{tabular}

Note: Reference category (1) 1997; (2) female; (3) low level education; (4) Denmark

Number of obs $=738816$

Wald chi2 ()$=22082.23$

Prob $>$ chi $^{2}=0.0000$

Log pseudolikelihood $=-45995.1$

Pseudo $\mathrm{R}^{2}=0.12$ 
Figure 3: Logistic Regression Odds Ratios for the Transition to Employment from Unemployment the Previous Survey Year (t-1), in 2007 as compared with 1997.

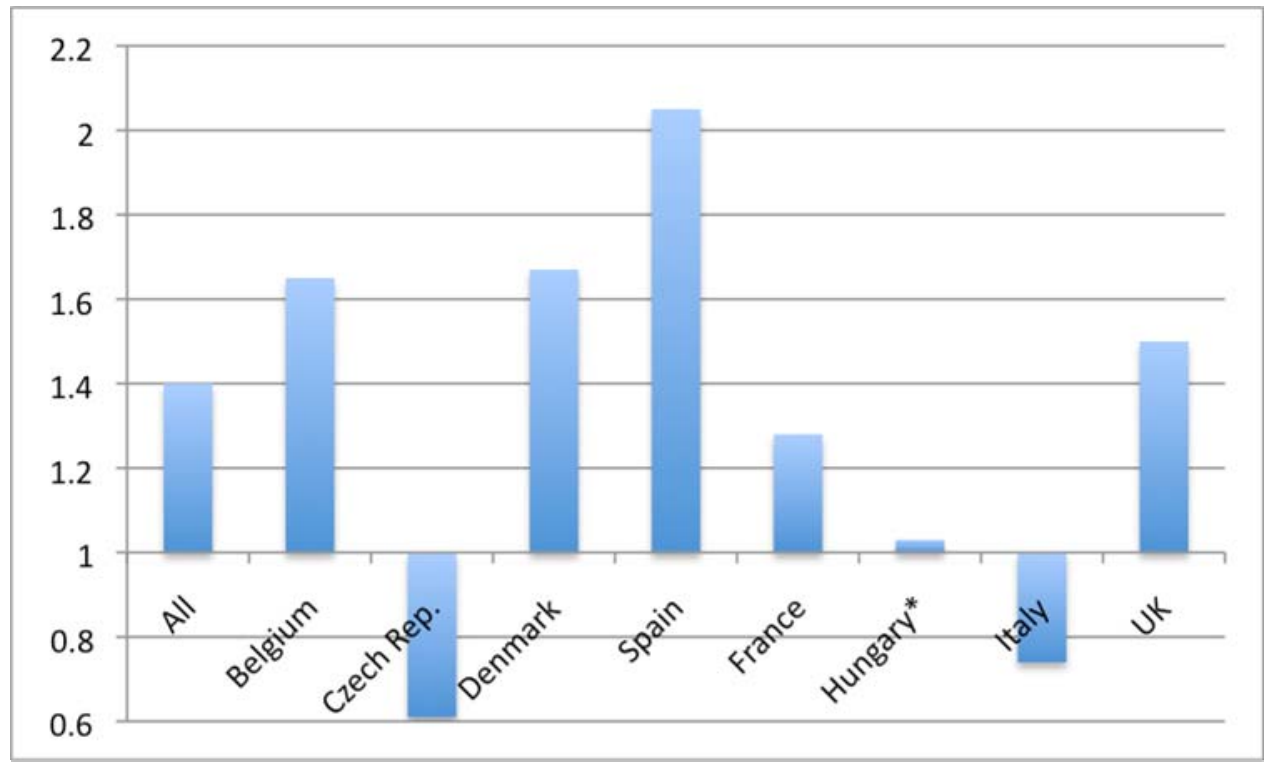

*Odds ratio not statistically significant 
Figure 4: Logistic Regression Odds Ratios for the Transition to Employment from Inactivity the previous survey year (t-1), in 2007 as compared with 1997

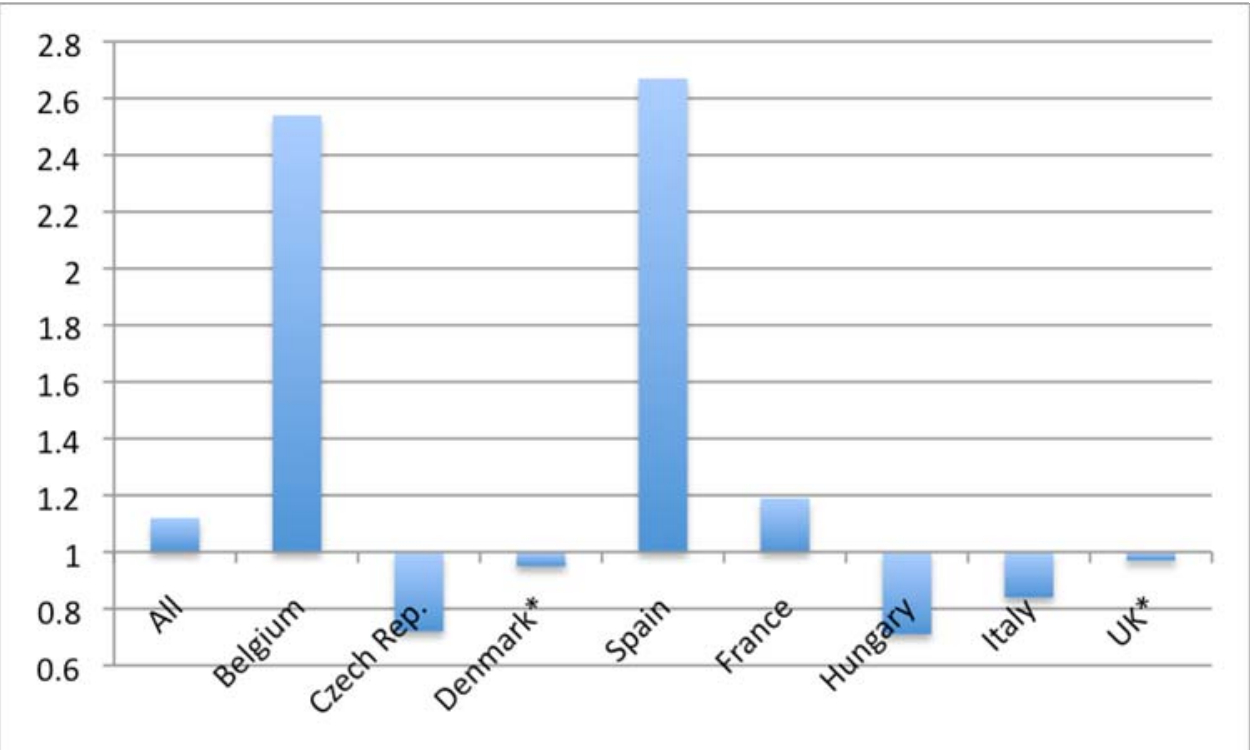

*Odds ratio not statistically significant 
Table 5: Logistic regression: Transition into permanent contract from non-employment (unemployment and inactivity)

\begin{tabular}{|c|c|c|c|c|c|c|}
\hline \multicolumn{7}{|c|}{ Transition into permanent contract } \\
\hline & $\begin{array}{l}\text { Odds Ra- } \\
\text { tio }\end{array}$ & $\begin{array}{l}\text { Robust } \\
\text { Std. Err. }\end{array}$ & $\mathbf{z}$ & $\mathbf{P}>\mathbf{z}$ & $\begin{array}{l}95 \%( \\
\text { val } \\
\end{array}$ & lence Inter- \\
\hline $2007(1)$ & 0.93 & 0.02 & -3.00 & 0.003 & 0.89 & 0.98 \\
\hline Male (2) & 0.83 & 0.02 & -7.71 & 0.000 & 0.79 & 0.87 \\
\hline age & 1.07 & 0.006 & 12.54 & 0.000 & 1.06 & 1.08 \\
\hline age $^{2}$ & 0.999 & 0.00008 & -12.87 & 0.000 & 0.9989 & 0.9992 \\
\hline $\begin{array}{l}\text { High level } \\
\text { education } \\
\text { (3) }\end{array}$ & 0.90 & 0.03 & -3.00 & 0.003 & 0.84 & 0.96 \\
\hline $\begin{array}{l}\text { Medium } \\
\text { level edu- } \\
\text { cation (3) }\end{array}$ & 0.99 & 0.03 & -0.28 & 0.781 & 0.94 & 1.04 \\
\hline Country (4) & & & & & & \\
\hline Belgium & 0.55 & 0.02 & -14.67 & 0.000 & 0.50 & 0.59 \\
\hline Czech Rep. & 0.59 & 0.02 & -14.70 & 0.000 & 0.55 & 0.64 \\
\hline Denmark & 0.97 & 0.05 & -0.62 & 0.533 & 0.88 & 1.07 \\
\hline Spain & 0.11 & 0.005 & -48.54 & 0.000 & 0.10 & 0.12 \\
\hline France & 0.25 & 0.01 & -35.40 & 0.000 & 0.23 & 0.27 \\
\hline Hungary & 0.82 & 0.03 & -4.87 & 0.000 & 0.75 & 0.89 \\
\hline Italy & 0.35 & 0.01 & -33.63 & 0.000 & 0.33 & 0.37 \\
\hline $\begin{array}{l}\text { GDP } \\
\text { growth }\end{array}$ & 0.94 & 0.01 & -8.50 & 0.000 & 0.93 & 0.95 \\
\hline $\begin{array}{l}\text { Agriculture } \\
\text { (5) }\end{array}$ & 0.34 & 0.02 & -17.57 & 0.000 & 0.30 & 0.38 \\
\hline Industry (5) & 1.05 & 0.03 & 1.66 & 0.096 & 0.99 & 1.12 \\
\hline
\end{tabular}

Note: Reference category (1) 1997; (2) female; (3) low level education; (4) Denmark; (5) Service Number of obs $=87343$

Wald chi2 ()$=4750.42$

Prob $>$ chi $^{2}=0.0000$

Log pseudolikelihood $=-11001$

Pseudo $\mathrm{R}^{2}=0.11$ 
Figure 5: Logistic Regression Odds Ratios for the Transition to a Permanent rather than a Temporary Contract, in 2007 as compared with 1997.

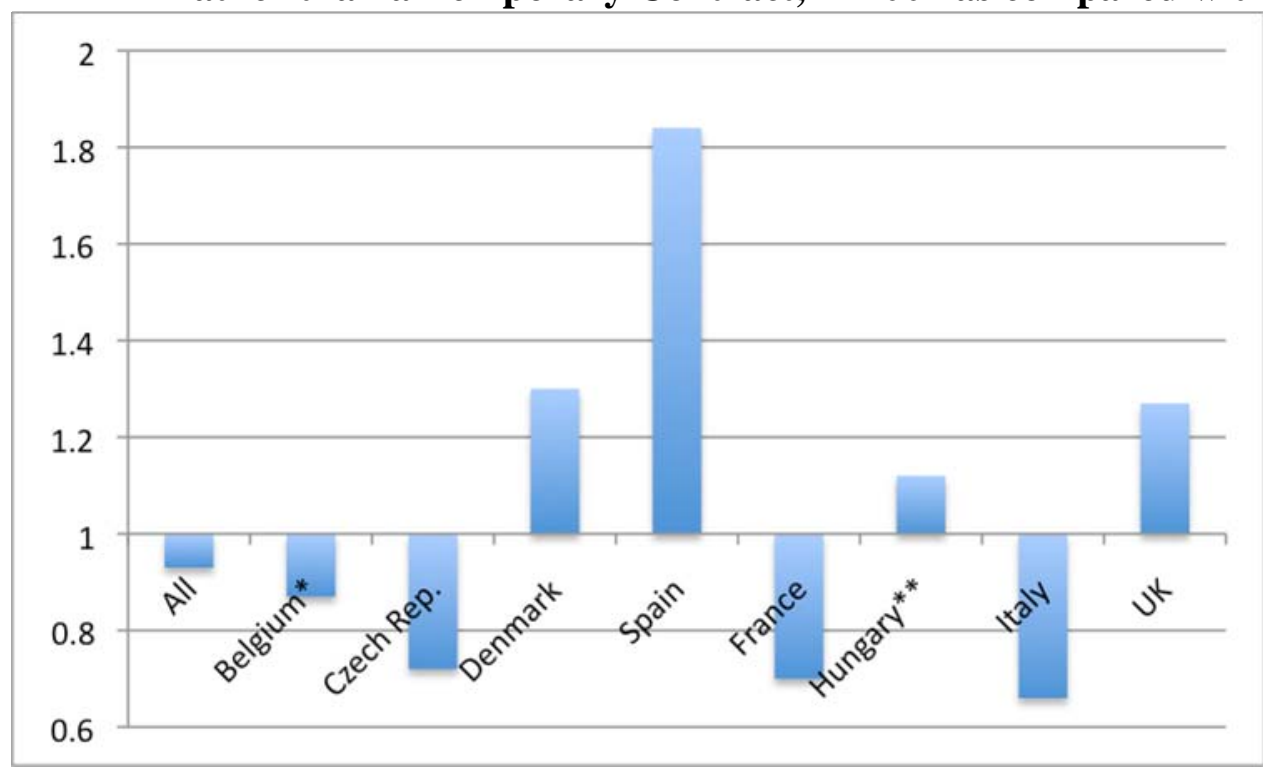

*Not statistically significant

**Statistically significant at the $10 \%$ level only 